\title{
大店法下における大型店の立地状況とその周辺環境の評価* 一新潟県でのケーススタディー
}

\author{
松本昌二 ${ }^{* *} \cdot$ 村田俊雄 ${ }^{* * *}$ ・宮腰和弘 ${ }^{* * * *}$
}

Shoji MATSUMOTO, Toshio MURATA and Kazuhiro MIYAKOSHI

\section{1.はじめに}

大規模小売店舗法（大店法）は、昭和 48 年の施行以 来厳しく運営されて、その行き過ぎの規制に対して批判 もあった。1990年代に入り、米国が規制緩和を強く要望 するようになり、平成 4 年 (1992) 改正大店法が施行さ れ、商調協（商業活動調整協議会）が廃止された。商業 調整の場が国と県の大規模小売店舗審議会 (大店審議会) に移り、市民参加は大店審議会主導の意見聴取会議に なったため、通過儀礼的傾向が強くなった。一方、自動 車保有台数の増加により、買物行動は広域化したため、 郊外大型店の出店が加速することになった。

90 年代も中盤を過ぎると、大型店が周辺の地域環境 に及ぼす問題が表面化されてきた。しかし、大店法は交 通渋滞、駐車場の容量確保、騒音、ゴミ等の問題に対し て無力であった。また大店法の需給調整が、これらの問 題の顕在化で時代にそぐわなくなってきたともいえる。 米国は再三にわたって大店法の廃止を要求してきた。

そのような流れの変化を受け、1997年末政府は大店法 の廃止を決定し、大型店の出店を環境面から規制する大 規模小売店舗立地法 (大店立地法) が 2000 年 6 月から施 行された。

さて、大店法の需給調整の下で出店した大型店につい て、周辺環境の影響評価を行った研究事例は少ない。ま た大型店周辺地域の居住者の意見を調查した事例も少な い。 ${ }^{1) 2)}$

そこで本研究では、新潟県をケーススタディとして、 大店法による需給調整、大型店の立地、それによる商圈 や地域構造の変化等を分析する。次に、大型店の駐車場 や交通実態、周辺環境影響の評価、周辺住民の意識を把 握する。大店法のもとで出店した大型店について、需給

*キーワード : 都市計画、産業立地、交通公害

**正員 工博 長岡技術科学大学環境 - 建設系教授

（長岡市上富岡町 1603-1、

TEL:0258-47-9615 FAX:0258-47-9650)

***正員 工修 開発技研(㑣)（新潟市文京町 22-21、

TEL:025-265-2261 FAX:025-233-8588)

****正員 工博 長岡工業高等専門学校

環境都市工学科助教授（長岡市西片貝、

TEL:0258-34-9280 FAX:0258-34-9284)
調整、環境影響、地域づくりの 3 視点からアプローチす ることにより、大店立地法とその運用にかかわる課題を 検討することを目的とする。

\section{2. 研究の視点と方法}

大店法の目的は、消費者の保護と周辺小売業の事業活 動の保護であり、出店する店舗は、規模により第一種· 第二種に分けられ需給調整が行われてきた。規制の対象 となるのは、店舗の開店日、店舗面積、閉店時刻、年間 休業日数であり、「調整 4 項目」とよばれる。また出店時 は、(1)開発許可申請·出店計画概要書の作成、(2)所轄警 察署や道路管理者との出入口や安全性に関した協議、(3) 大規模小売店舗審議会(意見聴取会議を開催する)、(4)建 築申請といった手順を経て店舗の建築に至る。

一方、大店立地法の目的は、その周辺地域の生活環境 の保持のため大型店施設の配置と運営方法の適正化であ る。第 4 条の「指針」では、需給調整的な運用を禁止し、 以下のような大型店設置者が配慮すべき事項を定めてい る。3)

(1)駐車需要の充足等、交通に係わる事項

(2)歩行者の通行の利便確保等

(3)廃棄物の減量化及びリサイクルへの配慮

(4)防災対策への協力

(5)騒音の発生に係わる事項

(6)廃棄物の保管、運搬に係わる事項

\section{表- 1 分析視点·内容·使用するデータ}

\begin{tabular}{|c|c|c|c|}
\hline 分析視点 & 分析内容 & 使用するデー夕 & 備考 \\
\hline 調整項目 & $\begin{array}{c}\text { 開店日 } \\
\text { 店舗面樍 } \\
\text { 閴店時刻 } \\
\text { 休業日数 }\end{array}$ & $\begin{array}{l}\text { 第一種·第二種大䙺模小売 } \\
\text { 店舗審議会議事 }\end{array}$ & $\begin{array}{l}\text { 全県 } \\
\text { レベル }\end{array}$ \\
\hline \multirow{5}{*}{ 周边轘境 } & 駐車場·交通 & 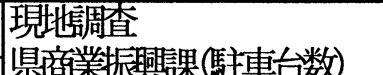 & \multirow{5}{*}{$\begin{array}{l}\text { 個店 } \\
\text { レベル }\end{array}$} \\
\hline & 騷音 & 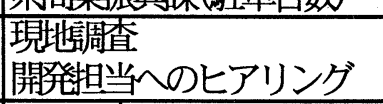 & \\
\hline & 廃童物 & $\begin{array}{l}\text { 現地他垌 } \\
\text { 開発担当へのヒアリング }\end{array}$ & \\
\hline & その他 & 観察による & \\
\hline & 周辺拄民 & \begin{tabular}{|l} 
店舗周辺住民への \\
意識アンケート調査
\end{tabular} & \\
\hline
\end{tabular}




\section{(7)街並みづくりへの配慮等}

このように大型店の出店・運用を検討するに当たって は、表- 1 に示すように、大店法の需給調整・出店調整 というマーケティングの競争性をみる視点及び大店立 地法の大型店周辺環境をアセスメントする視点が存在す る。さらに、大店立地法のいう狭い意味での環境アセス ではなく、街づくりの計画性を見る視点が必要である。 大店立地法の「第 4 条の指針（案）の策定に当たって」 では、地域づくり・街づくりの計画性、総合性に言及し ているが、「第 4 条の指針」では含まれていない。 ${ }^{334}$

本研究では、これら 3 つの視点から、新潟県内大型店 の立地とその影響を分析し評価する。すなわち、新潟県 内大型店の立地と需給調整を分析し、主要都市について 商圈の動向、及び地域構造の変化について分析を行う。 次に、主要都市から抽出した大型店をケーススタディと して、周辺の交通環境と住環境を評価する。

これら分析結果は、もとより大店法下における大型店 立地の効果や影響であるが、その実証分析を受けて、大 店立地法が前提とする環境アセスの問題点を抽出し、街 づくりの計画性について今後の課題を検討する。

\section{3. 県内大型店の立地と地域商業の変化}

\section{(1) 大型店の立地状況}

新潟県内の第一種大型店(店舗面積 $3000 \mathrm{~m}^{2}$ 以上)、第 二種大型店 (店舗面積 $500 \mathrm{~m}^{2}$ 以上 $3000 \mathrm{~m}^{2}$ 未満)について新 規開店状況を経年的にみる (図 -1$)^{5}$ 。平成 5 年前後を 境にして出店数が急増しているのがわかる。れは平成 4 年大店法の規制緩和が実施され、審議期間が 1 年以内 になって、小売業者としても出店しやすくなったからと 思われる。

平成 9 年の県内大型店数は536 店（第一種 128 店、第 二種 408 店）となり、平成 6 年と比較すると $30.1 \%$ の増 加となる。県内の大型店占有率(小売業売場面積に対す る第一、二種大型店の店舗面積の割合) は $43.3 \%$ に達し た。さらに、市町村人口に対して大型店占有率の関係を みる(図-2)。人口 6 万人以上の都市では一様に大型店 の占有が進んでいるが、それ以下の人口の市町村では大 型店占有に偏りがみられる。

大型店の立地場所をみると、買物行動の変化として後 述するように、昔からの商店街との関係は薄く、都市の 周辺市街地ないし郊外に立地するものが大部分である。 大型店同士の競合の結果として、中心部での閉店、中心 部から郊外に、さらには郊外からさらに郊外へと、大型 店の立地が変化してきたのが害態である。

\section{（2）店舗面積の調整}

大規模小売店舗審議会 (大店審議会) 議事報告 ${ }^{6}$ によ り、調整 4 項目の中で最も重要と思われる店舗面積に

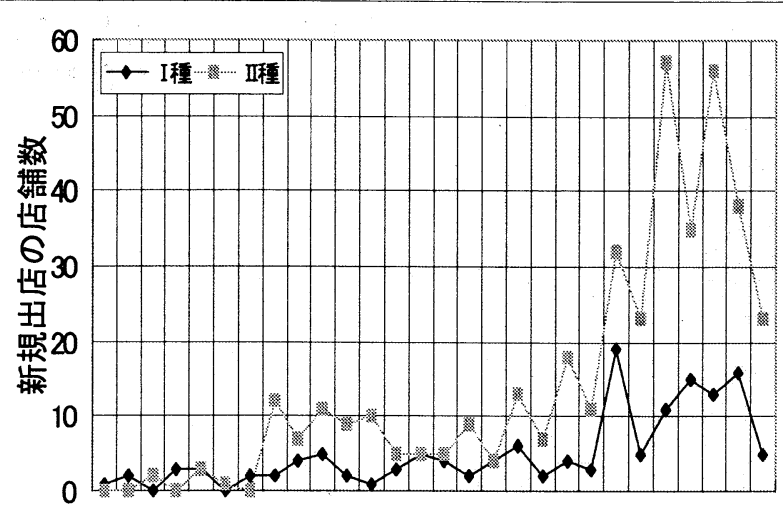

S47 S49 S51 S53 S55 S57 S59 S61 S63 HR HA HO HB HIO

年

図 - 1 第一種·第二種大型店の新規出店店舗数

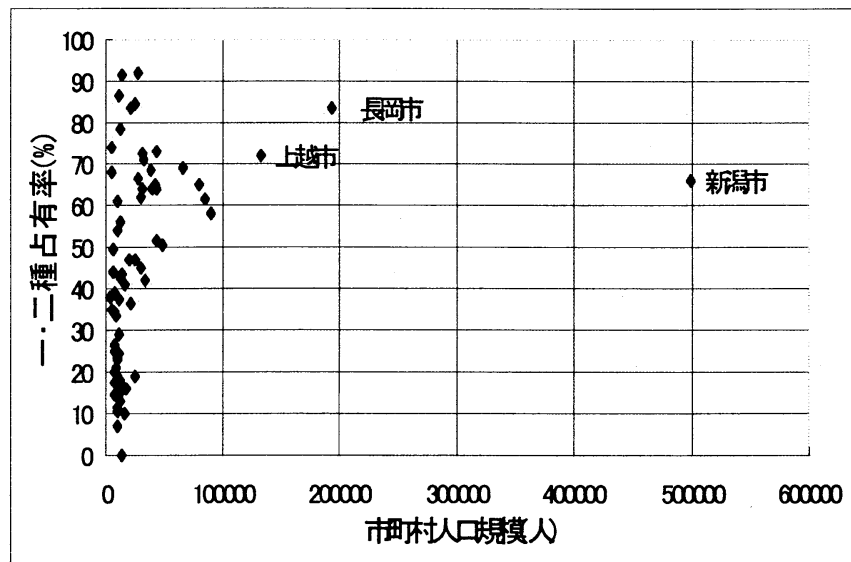

図 - 2 市町村人口規模と大型店占有率

\section{表- 2 大店審における店舗面積の調整}

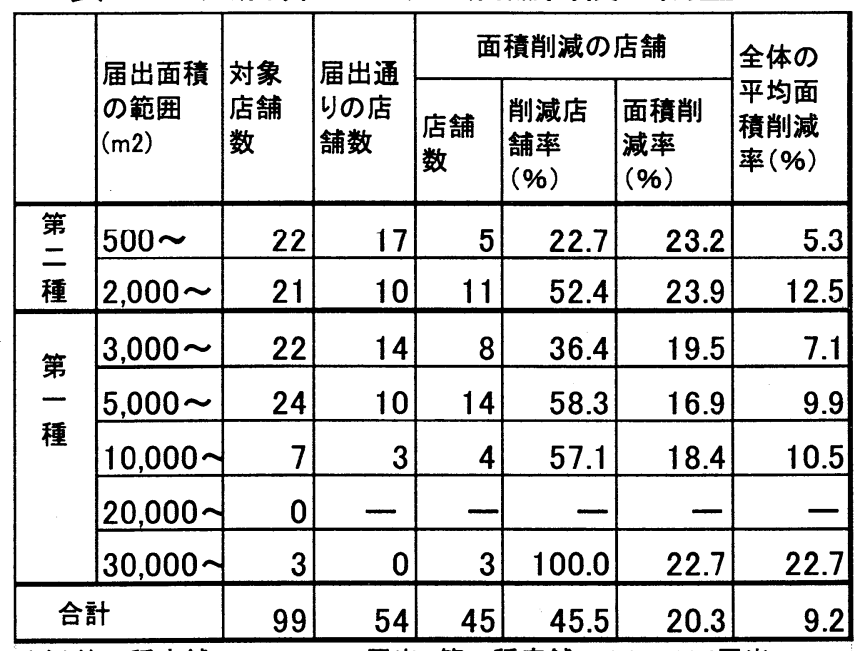

(注) 第一種店舗: H6.1-H11.10届出、第二種店舗: $\mathrm{H} 8.3-\mathrm{H} 11.4$ 届出.

限って調整結果を分析する。対象とするのは、およそ平 成 11 年以降に新規出店した大型店であり、第一種 56 店、 第二種 43 店となった（表- 2 ）。届出の店舗面積が削減 されたのは全体の $46 \%$ であり、その面積削減率は $20 \%$ であった。届出通りの店舗面積が認められた店も含める と、面積削減率は $9 \%$ となる。国の規制緩和政策に従つ た調整が実施されたとみることができよう。審議会が異 なる第一種と第二種を比べると、第一種に対してはより 


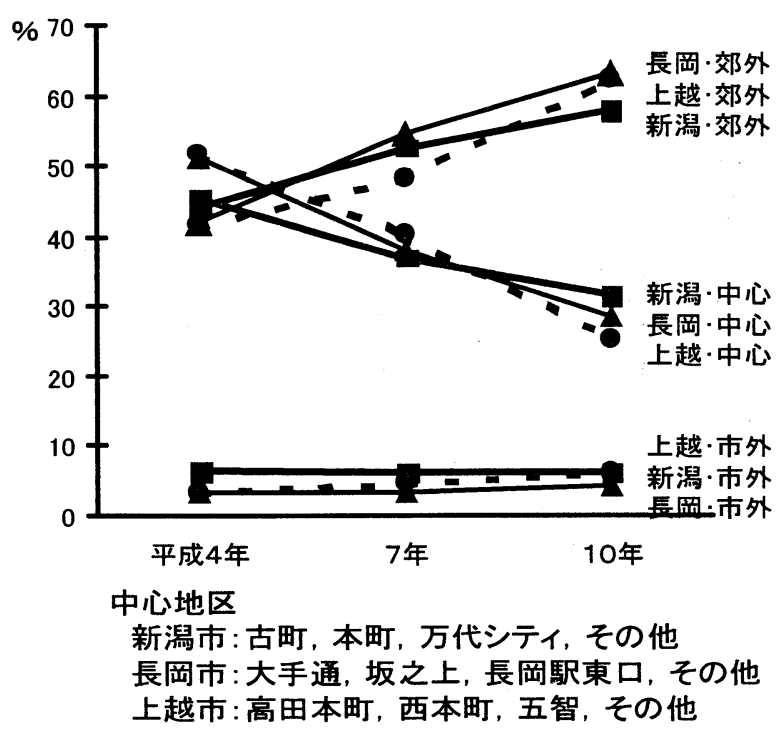

図-3 買回品の買物地区利用割合の推移

多くの店舗を削減対象としたが、その面積削減率は幾分 小さかった。第二種を扱う新潟県大店審においては、地 元の意見聴取会議や商工会議所の意見に地域差がみら れ、地元意見を重視した結果が表れていると考える。意 見聴取会議では、調整 4 項目の問題ではなく、交通、騒 音など周辺環境の問題点がしばしば指摘され、大店審に おいても議論されたけれども、大店審では周辺環境を調 整理由とすることができないので、参考意見として扱う のみであった。

(3) 商圈と地域構造の変化 ${ }^{7), 8)}$

新潟県が 3 年毎に実施している「広域商圏動向調査」 により、新潟市、長岡市、上越市について商圏の変化(昭 和 52 年〜平成 9 年）をみる。 3 市の間に大きな違いは なく、商圈人口、購買人口は緩やかに増加する。一方、
商圈内シェアは減少傾向にあり、買回品より最奇品で減 少が大きい傾向にある。既に図- 2 に示したように、中 心都市外の周辺市町村に、最寄品を主体とした大型店が 偏在しつつも立地したからと思われる。

3 市の商業地を中心地区 (中心商店街) と郊外地区に 分けて、地区利用割合の推移をみると、買物行動の郊外 化、中心部の空洞化が明確に現れる(図-3)。図-3は 買回品の場合であるが、最寄品はそれ以上に中心地区の シェアが落ち込んでいる。さらに、3市より人口規模の 小さい中小都市の多くで、中心地区 (中心商店街) の空 洞化は見るに耐えない状況に至っている。一方、郊外の 新しい商業地で、日祭日には駐車場がクルマで一杯にな り、交通渋滞が発生する。

3 市の中心商店街は、空き店舗対策、ポイントカード 事業、共通駐車券、買物バス券、イベントなど活性化に 取り組み、3市は「中心市街地活性化基本計画」を策定 した。しかし、商店主の危機意識の不足、希薄な連帯感、 集客力の不足、後継者不足の共通した問題点が指摘され ている。

ここでは小売業の立地、商圈、買物行動の変化のみに 着目したが、地域構造の変化は当然それだけではない。 中心市街地での定住人口の減少、役所・病院等の公共公 益施設の郊外化、郊外での低密市街地の開発、そしてク ルマ使用を強制し、公共交通を衰退させる都市構造な ぞ、地域づくりに関する問題は深刻な状況にあると言え よう。大型店の立地問題は、そのような地域構造を変化 させる要因の一つであり、その計画性の課題については 本論文の最後で言及する。

表-3 大型店の周辺環境調査とアンケート調査

\begin{tabular}{|c|c|c|c|c|c|c|c|}
\hline \multicolumn{2}{|c|}{ 大型店 } & Dekky401 & $\begin{array}{c}\text { ランドクラブ } \\
\text { 新潟 }\end{array}$ & $\begin{array}{c}\text { ランドクラブ } \\
\text { 長岡 }\end{array}$ & リップス & $\begin{array}{l}\text { ジャスコ } \\
\text { 新潟東 }\end{array}$ & $\begin{array}{l}\text { サティ } \\
\text { 吉田 }\end{array}$ \\
\hline \multicolumn{2}{|c|}{ 開店日 } & H6.9.30 & H7.4.28 & $\mathrm{H} 7.4 .1$ & $\mathrm{H} 11.7 .31$ & $\mathrm{H} 5.7 .3$ & S56.11.26 \\
\hline \multicolumn{2}{|c|}{ 店舗面積 } & 14044 & 11644 & 11115 & 5986 & 18500 & 3717 \\
\hline \multicolumn{2}{|c|}{ 閉店時刻 } & $21: 00$ & $20: 00$ & $20: 00$ & $20: 00$ & 21:00 & $21: 00$ \\
\hline \multicolumn{2}{|c|}{ 休業日数 } & 20日 & 20日 & 20日 & 20日 & 16日 & 20日 \\
\hline \multicolumn{2}{|c|}{ 駐車場台数 } & 1180 & 611 & 952 & 270 & 1500 & 150 \\
\hline \multicolumn{2}{|c|}{$\begin{array}{c}\text { アンケート配布 } \\
\text { 対象地区 }\end{array}$} & $\begin{array}{l}\text { 近江の一部 } \\
\text { 女池北 } 1\end{array}$ & \begin{tabular}{|l|} 
女池8-3〜 15 \\
鳥屋野の一 \\
部
\end{tabular} & $\begin{array}{l}\text { 南七日町 } \\
\text { の多< }\end{array}$ & $\begin{array}{l}\text { 川崎町の一 } \\
\text { 部、堀金1-2 } \\
\sim 5 \text { 、堀金2- } \\
1 \sim 11 \text { 、堀 } \\
\text { 金3-9〜12, } \\
15,16\end{array}$ & \begin{tabular}{|l|} 
大形本町 1 \\
4、 \\
逢谷内 $4,6 、$ \\
寺山3
\end{tabular} & $\begin{array}{l}\text { 春日町 } \\
\text { 日之出町 } \\
\text { 東栄町 }\end{array}$ \\
\hline \multicolumn{2}{|c|}{ 配布部数 } & 109 & 99 & 69 & 83 & 164 & 147 \\
\hline \multicolumn{2}{|c|}{ 回収枚数(枚) } & 61 & 60 & 54 & 68 & 93 & 85 \\
\hline \multicolumn{2}{|c|}{ 回収率(\%) } & 56.0 & 60.6 & 78.3 & 81.9 & 56.7 & 57.8 \\
\hline \multirow{2}{*}{\multicolumn{2}{|c|}{$\begin{array}{l}\text { 有効票数(枚) } \\
\text { 有効得票率(\%) }\end{array}$}} & 55 & 49 & 44 & 60 & 89 & 71 \\
\hline & & 90.2 & 81.7 & 81.5 & 88.2 & 95.7 & 83.5 \\
\hline \multirow[b]{2}{*}{ 用途地域 } & 店舗所在地 & 近隣商業 & 準住居 & 準工業 & 近隣商業 & 工業 & 近隣商業 \\
\hline & アンケート範囲 & $\begin{array}{c}\text { 準工業 } \\
\text { 第一種住居 }\end{array}$ & \begin{tabular}{|c|} 
第一種住居 \\
第二種 \\
中高層住専 \\
\end{tabular} & $\begin{array}{c}\text { 第二種 } \\
\text { 中高層住専 }\end{array}$ & $\begin{array}{c}\text { 第一種 } \\
\text { 中高層住専 }\end{array}$ & $\begin{array}{c}\text { 工業 } \\
\text { 準工業 }\end{array}$ & $\begin{array}{c}\text { 第一種住居 } \\
\text { 近隣商業 }\end{array}$ \\
\hline
\end{tabular}




\section{4. 大型店周辺の交通環境と住環境の評価}

\section{(1) 対象店舗と調査方法}

大店立地法の趣旨に添って、周辺環境の評価をケース スタディとして行った。表-3は、本研究で対象とした 6 店舗と地区、及びアンケート調査の概要を示す。アン ケート有効票数は、おおむね 50 票以上である。

店舗の選定に当たっては、(1)規制緩和の影響を大きく 受けた平成 6 年以降に新規開店した店埔（2)近隣に住宅 地などがあり交通や住環境への影響が判断しやすい店 舗、の理由を考慮した。なお、ジャスコ新潟東店、サティ 吉田店は平成 6 年以前の開店であるが、新規開店と既存 店を比較する参考として選定した。サティ吉田店に関し ては、サティは平成 4 年に退店し、現在は他業者がテナ ントとして入っているが、ここでは慣用的にサティ吉田 店とよぶ。

\section{（2）交通環境の評価}

交通アクセス、駐車場、及び自動車騒音について測定、 観察によって休日に調查した。

(1)交通アクセス上の問題

・駐車場が幹線道路に面していない店舗、駐車場に隣接

して多くの住居が立地する店舗が見受けられた。

・店へ来訪する自動車が、旧来からの道路を利用する構

造になっている駐車場が見受けられた。

(2)駐車場について

・駐車のピークは $16-17$ 時台にある。

・駐車場はピーク時間帯で収容率 $90 \%$ 程度であり、ある

程度の余裕をもたせている。

図-4は、ランドクラブ長岡の例であり、周辺交通量 と駐車場利用の実態を示す。休日は午後 4 時頃にピーク が発生している。

(3)騒音について

・騒音は店舗より自動車からの方が多い。

・騒音はアクセス道路に沿って広がる。

\section{(3)住環境の変化の評価}

大型店が立地したことによって住環境がどう変化した かを、自然、景観、自動車利便性、徒歩、買い物利便性 等についてアンケート調査した。

図 - 5 の静けさに関しては、「悪くなった」「やや悪く なった」が 4 〜 割を占め、音環境の悪化を感じている 人が多いことがわかる。サティ吉田の評価が幾分高いの は、元々店舗面積が小さく周辺道路の交通量も少ないた めであろう。

図-6の景観に関しては、「変わらない」の割合が最も 多く、評価が割れている。ジャスコ新潟東での植裁は高 く評価され、自然や景観の形成だけではなく、遮音緩衝 帯としての効果が期待できる。

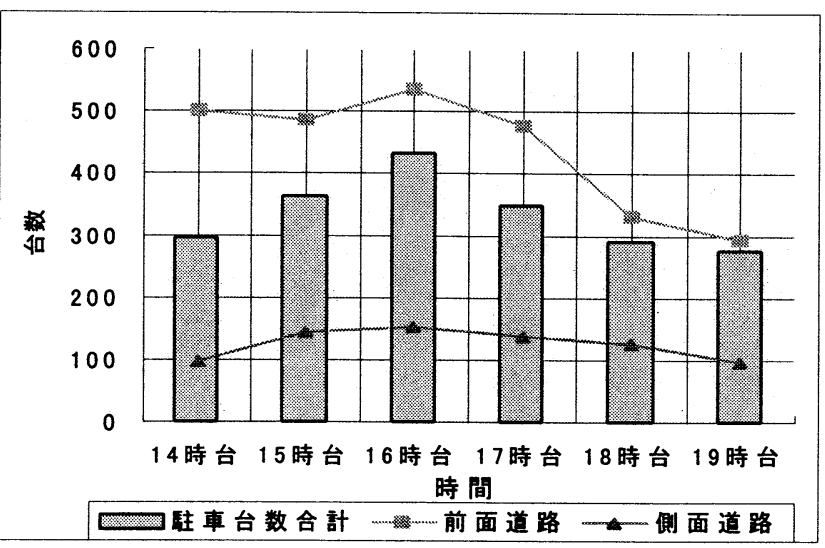

図 -4 ランドクラブ長岡の周辺交通量と駐車場利用

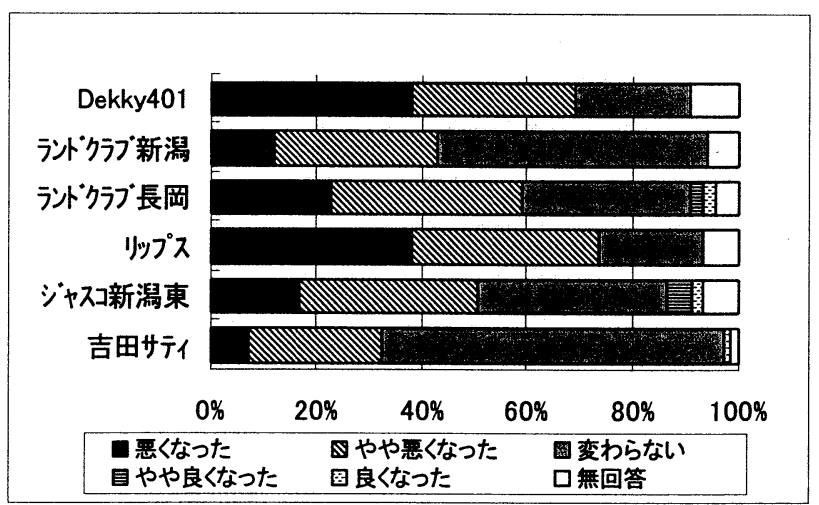

図 - 5 住環境の変化一静けさ

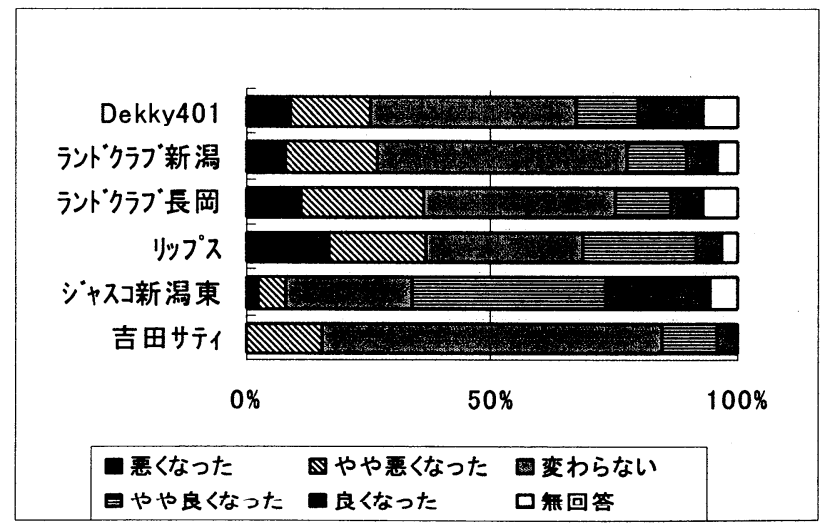

図-6 住環境の変化一景観

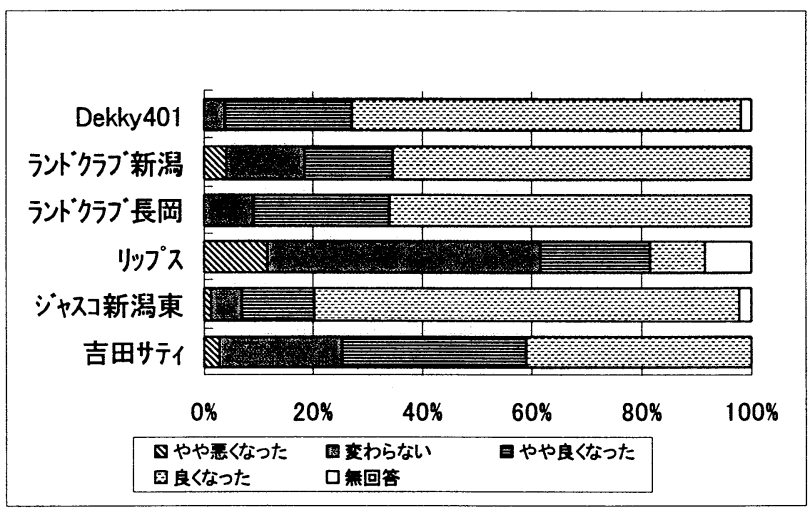

図 - 7 住環境の変化一買物の利便性

図-7の買物利便性については、静けさとは対照的に 「良くなった」「やや良くなった」が 8～9割を占めて、圧 倒的に高く評価された。

ただし、ここの評価で特に目立つのは、リップスであ る。騒音で不満を持たれ、買物利便性も好い評価はほと 
表-4 大型店に対するマイナス評価の理由 (単位 : \%)

\begin{tabular}{|l|r|r|r|r|r|r|}
\hline & $\begin{array}{c}\text { Dekky } \\
401\end{array}$ & $\begin{array}{c}\text { ランドク } \\
\text { ラブ新潟 }\end{array}$ & $\begin{array}{l}\text { ランドグ長岡 } \\
\text { リップス }\end{array}$ & $\begin{array}{c}\text { ジャスコ } \\
\text { 新潟東 }\end{array}$ & $\begin{array}{c}\text { サティ } \\
\text { 吉田 }\end{array}$ \\
\hline 違法駐車が多い & 8.0 & 0.0 & 10.9 & 10.6 & 3.4 & 3.4 \\
\hline 照明灯がまぶしい & 1.8 & 0.0 & 0.0 & 3.5 & 1.1 & 1.7 \\
\hline 日照が悪い & 0.0 & 0.0 & 1.6 & 1.4 & 0.0 & 0.0 \\
\hline 車の往来が増えた & 45.5 & 52.3 & 45.3 & 35.9 & 43.8 & 33.9 \\
\hline 悪臭等 & 1.8 & 4.6 & 4.7 & 6.3 & 0.6 & 1.7 \\
\hline 啮滞が発生 & 30.4 & 18.5 & 14.1 & 31.7 & 30.1 & 36.4 \\
\hline 風紀が乱れる & 7.1 & 7.7 & 7.8 & 7.0 & 13.6 & 2.5 \\
\hline その他 & 3.6 & 1.5 & 1.6 & 1.4 & 0.0 & 6.8 \\
\hline 特になし & 0.0 & 3.1 & 6.3 & 0.7 & 2.8 & 0.0 \\
\hline 無回会 & 1.8 & 12.3 & 7.8 & 1.4 & 4.6 & 13.6 \\
\hline
\end{tabular}

んど得られなかった。同店舗は取扱品目や対象購買層 が限定され過ぎ、周辺の住民 (中年〜高齢者が多い)に よる利用がほとんど無いこと、及びアクセス道路で休 日に渋滞が発生していることから、地域にとっては迷 惑であると評価されている考えられる。また、サティ吉 田店の評価が幾分他の店と異なるのは、開店が 20 年前 であることが影響していると思われる。

\section{(4)現状の住環境の評価}

表一 4 は各店舗に対する他のマイナス評価の理由割 合である。大多数を占めるのは、自動車交通が増えて渋 滞が発生している、違法駐車が多いという交通問題に 関する理由である。

周辺住民による各環境要素の評価結果をみると、上 位回答から以下が指摘できる。

・店側の騒音対策自体は意識されないことが多く、対応 上の問題は少ない。

・周辺道路の騒音、交通渋滞が上位を占めたが、店舗の 努力だけでは解決できない場合もある。また、上位 項目ではないが、閉店後駐車場に乗り入れる車や若 者が迷惑であるという意見が少数ながらあった。

\section{5. おわりに}

以上、大店法の下での分析結果を要約する。

(1)県内市町村の多くで、1990 年代に大型店の出店が一

段と活発になり、小売業の大型店占有率が極めて高 くなったが、それは国の規制緩和に沿った大店法の 運用、需給調整の結果である。

(2)新規の大型店出店の多くは郊外立地であり、商圈は 市町村域を越えて拡大した。中心地区（中心商店街） 側はその変化に対応できなかったため、中心市街地 の空洞化、衰退を招いた。

(3)大型店周辺環境の害態調查によれば、周辺住民には 不満の意見が多いこと、大型店からの廃棄物や騒音 といった実害は少なく、むしろアクセス道路の交通
騒音や渋滞といつた交通環境が問題であることがわ かった。

(4)大型店周辺の住環境評価によれば、静けさが悪化した、 自動車交通量が増えたという反面、買い物の利便性は 向上したと、各店舗に共通した評価結果が得られた。 (5)上述の実態調査結果、及び大規模小売店舗審議会にお いても大型店の周辺環境を䀣念する意見が多く出され たことから、大型店の出店に際して周辺環境アセスメ ントを行うことは十分な妥当性を持っている。 以上の実態に基づいて、2000年 6 月から施行された大 店立地法とその運用について、今後の問題点を検討する。

まず、既に述べたように、大店立地法は周辺地域の生 活環境を保持するため大型店施設の配置と運営方法の適 正化を目的としている。その第 4 条の「指針」である大 型店設置者が配慮すべき事項を検討すると、環境をアセ スメントする手法にいくつか問題点があると言えよう。 従って、大店立地法とその運用に関して、本研究の結果 から判断して、少なくとも以下の問題点を指摘すること ができる。

(1)大店立地法の施行下においても、道路管理者、公安委 員会等による交通協議は従来通り行政指導で行なわれる。 新潟県の場合でいえば、県庁内連絡協議会と大規模小売 立地審議会 (大店立地審議会) において交通協議の内容 が公開され調整されることになる。従来よりは情報公開、 透明性が改善されるが、周辺住民の意見や理解を求める 仕組みや努力が必要とされる。

(2)大店立地法 4 条の「指針」によれば、予測・評価の対 象となる騒音は駐車場からの騒音、敷地内における自動 車走行等による騒音などであり、大型店へのアクセス道 路における自動車走行の騒音は含まれていない。本研究 によれば、アクセス道路の騒音こそが問題であり、それ に対応する仕組みが必要となる。

(3)大店立地法 4 条の「指針」では、必要駐車場台数の計 算式を提示している。本研究では、既存店舗の駐車場台 数をこの計算式と比較することはしていない。同計算式 
の算定根拠は不明確であるため、新潟県の実状に合うの か、業種によってどう違うのか、検討が必要である。 (4)大店立地法において住民参加にかかわることは地元 説明会、地元住民・地元商工会議所の意見（縦覧）、及 び新潟県では大店立地審議会である。直接の利害関係を 持つ大型店周辺、近隣の商業者や住民の意見が強く反映 されることが懸念されるため、より広域的に住民の意見 を聞く機会を設けることが望まれる。アセスメントへの 住民参加を推進するために、地域独自のルールブくりが 必要である。

次に、「大店立地法第 4 条の指針（案）の策定に当たつ て」によれば、地域づくり・街づくりは総合的な取り組 みであり、公共投資、助成策、規制など多様なツールが 組み合わされることが必要であると認め、大型店立地の 適否の判断に直接かかわるものについては.都市計画法 等のいわゆるゾーニング的手法(特別用途地区の設定の 弾力化を含む)を活用することが不可欠であるとしてい る。実際「まちづくり 3 法」の一つの柱として、平成 10 年 5 月、都市計画法が改正されて、特別用途地域の指定 は市町村に権限を与え、市町村が設定できるようになっ た。しかし、市町村が中小小売店舗地区等の特別用途地 区を現実に指定できるかとなると極めて困難と思われ、 まして都市計画区域外の町村にとっては役に立たないこ とになると指摘されてきた。

大型店出店において地域づくり・街づくりの第 3 の視 点の重要性を認めつつも、国はそのために十分な対策を とらないまま、大店立地法をスタートさせたと言えよ
う。地域づくり・街づくりの視点から、地域の実情に あった、きめ細かい対応をするために、地域独自のルー ル「街づくり条例」が必要であるという意見が多い。9 それはもちろん大型店、小売業に限定されたものとは限 らないが、地域の取り組みが高まることを期待したい。

\section{〈参考文献〉}

1) 浅野純一郎、瀬口哲夫 (1995)、「幹線道路沿道に集積す る商業施設の立地構造に関する基礎的研究一長野県の 未線引き用途無指定地域を対象として一」、都市計画論 文集 No. 30、169-174.

2) 見角一郎・中出文平: 住居系地域へのコンビニエンス ストア立地が周辺住環境に与える影響に関する研究、 都市計画学会学術研究論文集、30、163-168、1995.

3) 通商産業省告示第 375 号「大規模小売店舗を設置す る者が配慮すべき事項に関する指針平成 11 年 6 月.

4）産業構造審議会流通部会・中小企業政策審議会流通小 委員会合同会議:「大規模小売店舗立地法第 4 条の指針 （案）の策定に当たって」平成 11 年 5 月 31 日.

5) 新潟県商工労働部商工振興課商業振興係資料、第一種 (及び同第二種) 大規模小売店舗台帳、平成 6 年 11 月 1 日現在

6) 新潟県商工労働部商工振興課商業振興係資料、第一種 (及び同第二種) 大規模小売店舗審議会議事審議結果

7) 新潟県商工労働部 : 新潟県広域商圈動向調查報告書、 平成 8 年 3 月

8) (財) 新潟経済社会リサーチセンター:「調査新潟県に おける中心商店街の現状とその課題」、センター月報 316、2000. 2.

9)まちづくり推進連絡協議会:続・まちづくり条例をつ くろう!、平成 12 年 11 月.

\section{大店法下における大型店の立地状況とその周辺環境の評価一新潟県でのケーススタディー}

松本昌二・村田俊雄・宮腰和弘 本研究は、新潟県をケーススタディとして、大規模小売店舗法 (大店法)による需給調整、大型店の立地、それによ る商圈や地域構造の变化等を分析する。次に、大型店周辺の交通実態、住環境の評価、周辺住民の意識を把握する。 大店法のもとで出店した大型店について、需給調整、環境影響、地域づくりの 3 つの視点からアプローチすることに より、2000 年 6 月より施行された大規模小売店舗立地法 (大店立地法) とその運用にかかわる課題を検討する。県 内市町村の多くで、1990年代に郊外大型店の出店が一段と活発になり、小売業の大型店占有率が極めて高くなつた。 中心地区 (中心商店街) 側はその変化に対応できなかったため、中心市街地の空洞化、衰退を招いた。大型店周辺の 住環境は、静けさが悪化した、自動車交通量が増えたと評価されており、大型店出店に際して周辺環境アセスメント を行うことは十分な妥当性を持っている。

Location of Large-Scale Retail Stores under Economic Regulation and their Impact Assessment on Neighborhood Environment - A Case Study in Niigata Prefecture -

Shoji MATSUMOTO, Toshio MURATA and Kazuhiro MIYAKOSHI

The law of large-scale retail stores (LSs) had economically regulated their new location and operation until 2000, and a completely new law for the location of LSs came into effect from June 2000. The study analyzes the location of LSs and consumers' shopping behavior during 1990's in Niigata Prefecture, and assesses traffic and living environment around some of LSs as a case study. The number of newly opened LSs grew very high during 1990's throughout Niigata Prefecture. Vitality of central shopping areas declined in most of cities. Inhabitants around the LSs revealed a unsatisfactory opinion mostly towards traffic jams of access route and traffic noise, particularly during operating hours late at night. The paper discusses several enforcement and operation issues to be faced by the new location law which are to environmentally assess impacts of the location of LSs. 